\title{
Potential for inoculation of common bean by effective rhizobia in Tunisian soils
}

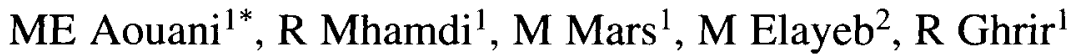 \\ 'Unité de biotechnologie végétale et de ressources génétiques, INRST, BP 95, 2050 Hammam Lif, Tunisia \\ ${ }^{2}$ Institut Pasteur, 13, place Pasteur, 1002 Tunis, Tunisia
}

\begin{abstract}
Summary - Phaseolus vulgaris (L) is poorly nodulated in all the regions of Tunisia where this crop is grown. Selection of effective strains needs to be developed. An effectiveness test trial was carried out on Royalnel and Coco cultivars in hydroponic aseptic conditions for seven reference strains and three local isolates of common bean rhizobia. A significant interaction strain $\times$ cultivar was observed and, unlike local isolates, most reference strains were very effective. The ELISA technique using polyclonal antibody was used to evaluate nodule occupancy of inoculated common bean rhizobia in Tunisian soils. Rabbit antisera were raised against one local isolate (HB) and five reference strains (CIAT899, USDA2667, USDA2669, USDA2676 and IRATYH112). Analysis of relatedness between 44 strains and isolates showed that $77 \%$ of the local isolates did not react with any of the sera used, whereas the remaining isolates were distributed into three serogroups. An inoculation experiment with the selected reference strains CIAT899, USDA2667 and IRATYH112, which are serologically distinguishable from native rhizobia, was performed in a green house for Royalnel and Coco cultivars grown in soil cores from two sites (Boucharrai and Chrifet). Nodule occupancy of the inoculated strains was assessed and concomitant effect of inoculation on nodule number and shoot nitrogen content was analysed. A highly significant treatment $\times$ cultivar $\times$ site interaction was observed for the parameters studied. While in Boucharraï soil inoculation leads to a significant improvement of shoot nitrogen content for Royalnel cultivar, inoculation of the same cultivar in Chrifet soil leads to an increase in nodulation by native rhizobia without improvement of plant growth. For the two cultivars, $\mathrm{N}$-fertilization leads for the two cultivars to a decrease in nodule number, particularly in Chrifet soil. Thus, to improve establishment of symbiotic process, the use of $\mathrm{N}$-fertilizer should be rationalized.
\end{abstract}

\section{inoculation / rhizobia / Phaseolus vulgaris / ELISA}

Résumé - Faisabilité d'inoculation du haricot par des Rhizobium efficients en sols tunisiens. Le haricot (Phaseolus vulgaris $(\mathrm{L})$ ) est faiblement nodulé dans toutes les régions de la Tunisie où il est cultivé. Pour sélectionner des souches efficientes un essai a été mené en système aseptique de culture hydroponique. Une interaction significative souche $x$ cultivar a été observée. Contrairement aux isolats locaux la plupart des souches de référence sont très efficientes. La méthode Elisa avec des anticorps polyclonaux a été utilisée pour évaluer l'occupation nodulaire des Rhizobium spécifiques du haricot inoculés dans les sols tunisiens. Des antisérums de lapin ont été préparés contre un isolat local (HB) et cinq souches de référence (CIAT899, USDA2667, USDA2669, USDA2676, and IRATYH112). L'analyse de l'apparentement entre 44 souches et isolats montre que $77 \%$ des isolats locaux ne réagissent pas avec ces sérums alors que les bactéries restantes forment trois sérogroupes. Une expérience d'inoculation avec les souches de référence sélectionnées CIAT899, USDA2667 et IRATYH112 distinguables sérologiquement des Rhizobium natifs, a été conduite en serre sur les cultivars Royalnel et Coco cultivés sur des carottes de sols provenant de deux sites différents (Boucharaï

*Correspondence and reprints 
et Chrifet). Le pourcentage de nodosités formés par les souches inoculées a été estimé et l'effet de l'inoculation sur le nombre de nodules et l'azote dans les parties aériennes ont été analysés. Une interaction hautement significative traitement $\times$ cultivar $\times$ site a été observée pour les paramètres étudiés. Alors que sur le sol de Boucharraï l'inoculation conduit à une amélioration significative du contenu en azote des parties aériennes pour le cultivar Royalnel, l'inoculation du même cultivar sur sol de Chrifet conduit plutôt à une stimulation de la nodulation par les bactéries natives sans amélioration de la croissance végétale. L'application d'engrais azoté conduit pour les deux cultivars à une diminution de la nodulation particulièrement sur sol de Chrifet. En vue de favoriser l'établissement du processus symbiotique, l'utilisation de ce composé doit être rationalisée.

inoculation / Rhizobium / Phaseolus vulgaris / Elisa

\section{INTRODUCTION}

Nitrogen fixation by legume-Rhizobium symbiosis is important to agricultural productivity and is therefore of great economic interest. Like many other food legumes, Phaseolus vulgaris (L), is generally grown in rotation with cereals. However, this food legume is known to exhibit a low ability to fix nitrogen (Larue and Patterson, 1981; Graham, 1981, 1992). This is perhaps partly due to the absence of appropriate rhizobial strains and to environmental variables (Smith et al, 1987; Bottomley, 1992). Indeed, for a long time, common bean varieties have been selected for soils with a high $\mathrm{N}$-content in developed countries. Defect in nitrogen fixation by the common bean will also affect soil nitrogen balance and growth of the subsequent crop (Keatinge et al, 1988). Lack of efficient nodulation in Tunisian soils has been observed for a long time (Dahmane et al, 1995), and this has perhaps favoured the wide use of $\mathrm{N}$-fertilizer for this crop.

A technique commonly used to improve legume growth, pod and grain yield, is inoculation with Rhizobium spp strains selected on the basis of their effectiveness. Nevertheless, these strains often fail to nodulate because they are unable to withstand environmental stress factors and/or to compete with well-adapted native rhizobia strains (Thies et al, 1992). Therefore, to identify rhizobia occupying nodules, and assess competitiveness, a reliable and sensitive method of identifying specific strains in nodules is required. This can be accomplished by a number of procedures. Serotyping is the most commonly used method for Rhizobium identification (Kishinevsky and Bar-Joseph, 1978; Ayanaba et al, 1986; Cleyet-Marel, 1987; Wolff et al, 1991).

In the present work we used ELISA (enzymelinked immunosorbent assay) for studying the relatedness between indigenous common bean rhizobia isolated from Tunisian soils and six reference strains. The usefulness of this technique in discriminating between reference and native rhizobia was evaluated. The symbiotic effectiveness of the six reference strains was measured on two common bean cultivars under laboratory conditions. Soil cores from two sites in the Cap Bon region (Chrifet and Boucharraï) were inoculated with these strains and nodule occupancy of the inoculant strains was assessed.

\section{MATERIALS AND METHODS}

\section{Biological material}

The origin and source of common bean Rhizobium are described in table I. Reference strains and local isolates were grown and maintained on YMA (yeast-mannitolagar) medium (Vincent, 1970). Two cultivars of Phaseolus vulgaris (L) were used in this work. They are grown by local farmers, Royalnel for green beans and Coco cultivar for grain production.

\section{Effectiveness test}

Ten rhizobia strains and isolates (table I) were tested in a preliminary experiment for symbiotic effectiveness on Coco and Royalnel cultivars. This experiment was performed using an aseptic $\mathrm{N}$-free hydroponic gravel culture system (Beck et al, 1993) in the glass house (using natural daylight, during March and April, with a temperature of $28^{\circ} \mathrm{C}$ by day and $15^{\circ} \mathrm{C}$ by night). The 20 treatments (ten strains $\times$ two cultivars) were replicated eight times in sterile disposable $0.5 \mathrm{~L}$ plastic cups (one plant/cup) three quart full of sterile gravel. Surface sterilized seeds were pregerminated in agar $0.9 \%$, sown in pots, and irrigated with the modified sterile $\mathrm{N}$-free nutrient solution of Broughton and Dillworth (Somasegaran and Hoben, 1985) (Fe(II)EDTA instead of Fe-citrate). The nutrient solution was provided to 
Table I. Sources of common bean rhizobia.

\begin{tabular}{lcc}
\hline Reference strains and local isolates & Origin & Source \\
\hline Reference strains: & & \\
GB9.6* & Gembloux, Belgium & Colombia \\
CIAT899* & Rwanda & CIAT \\
IRATYH $12^{*}$ & Washington & CIRAD, P Beunard \\
USDA2667* & - & USDA, P Van Berkum \\
USDA2668* & - & USDA, P Van Berkum \\
USDA2669* & Colombia & USDA, P Van Berkum \\
USDA2676* & & USDA, P Van Berkum \\
& & \\
Local isolates: & North of Tunisia & This study \\
HB*,15c3,16c1, 18b1,20c1, & This study \\
$23 \mathrm{c} 1,25 \mathrm{c} 2,28 \mathrm{~b} 3,28 \mathrm{c} 2,30 \mathrm{c} 2$, & North of Tunisia & This study \\
$31 \mathrm{a} 2,31 \mathrm{c} 3,33 \mathrm{a} 3,33 \mathrm{c} 3,34 \mathrm{~b} 2$, & North of Tunisia & This study \\
$34 \mathrm{c} 2,35 \mathrm{a} 1,35 \mathrm{~b} 2,35 \mathrm{c} 1,35 \mathrm{c} 2$, & North of Tunisia & This study \\
$36 \mathrm{~b} 3,36 \mathrm{c} 1,37 \mathrm{~b} 1,37 \mathrm{c} 2,39 \mathrm{~b} 2$ & North of Tunisia & This study \\
$107^{*}, 108^{*}, 1 \mathrm{~b} 3,2 \mathrm{~b} 1,2 \mathrm{~b} 3$, & Cap Bon, Tunisia & This study \\
$3 \mathrm{~b} 1,3 \mathrm{~b} 3,6 \mathrm{~b} 1,6 \mathrm{~b} 3,7 \mathrm{a} 3,7 \mathrm{c} 1$, & Cap Bon, Tunisia & This study \\
$8 \mathrm{a} 3,9 \mathrm{~b} 1,10 \mathrm{a} 3,12 \mathrm{a} 3,12 \mathrm{~b} 2$, & Cap Bon, Tunisia & \\
\hline
\end{tabular}

* Strains and isolates used in the effectiveness test trial. FSAG: Faculté des sciences agronomiques de Gembloux, Belgium. USDA: United States Department of Agriculture, Beltsville, MD, USA. CIAT: Centro Internacional de Agriculture Tropicale, Cali, Colombia. Cirad: Centre de coopération internationale en recherche agronomique pour le développement, Montpellier, France.

each cup by an automatic syringe. Plants were inoculated with $1 \mathrm{~mL}$ of rhizobial culture containing $10^{9}$ bact $/ \mathrm{mL}$ at seedling emergency and irrigated alternately with a $\mathrm{N}$-free solution or sterile distilled water. In addition, two non-inoculated controls, one receiving $100 \mathrm{ppm} \mathrm{NO}_{3}-\mathrm{N}$ in the nutrient solution ( $\mathrm{N}$-control), the other only the $\mathrm{N}$-free solution ( $\mathrm{N}$-control), were added to the trial. This last control permitted us to verify the sterility of the culture system and to evaluate the residual growth using only seed N. Six weeks after sowing, plants were harvested. Shoots were excised; then, nodules were enumerated and detached from their roots. All these parts were oven-dried, weighed and total nitrogen was determined (Bremner, 1965).

\section{Preparation of antigens and antisera}

Five reference strains (CIAT899, USDA2667, USDA2669, USDA2676 and IRATYH112) and one local isolate (HB) were grown on YMA for 3 days. Culture was then harvested in phosphate buffer saline (PBS) and vortexed. Numbers of bacteria were estimated by using plate counting procedures (Vincent, 1970). Cells were centrifuged and washed three times and resuspended in sterile $\mathrm{NaCl}(0.85 \%)$ solution and diluted to $10^{9} \mathrm{bact} / \mathrm{mL}$ to immunize rabbits with similar amounts of antigens. Suspensions were dispensed in sterile bottles and stored at $4{ }^{\circ} \mathrm{C}$ until immunization. In accordance with the schedule described by Beck et al (1993), antisera were obtained from young adult New Zealand white rabbits. After each bleeding, serum blood fraction was isolated and stored at $-20^{\circ} \mathrm{C}$.

\section{Relatedness between common bean rhizobia}

Serological relatedness of common bean Rhizobium strains and isolates was assessed using the six sera described above. Fresh Rhizobium culture on YMA slant was suspended in PBS and adjusted to the same turbidity $\left(\mathrm{A}_{620}=0.20\right)$ and diluted 50-fold before use with the coating solution $(5 \mathrm{mM}$ carbonate buffer to pH 9.6). Microtiter plates, 96 wells (Immulon II) were used. Indirect ELISA was performed as described by Beck et al (1993) with an automatic ELISA plate reader (Multiscan MCC/340) according to the following.

i) Tested bacteria were added to the wells (100 $\mu \mathrm{L} /$ well), and incubated for $90 \mathrm{~min}$ at $37^{\circ} \mathrm{C}$.

ii) Plates were then washed ten times with PBS containing $0.1 \%$ Tween $20(100 \mu \mathrm{L} /$ well $)$.

iii) In order to ensure complete inhibition of nonspecific binding, PBS Tween 20 containing $0.5 \%$ bovine serum albumine was added to the wells $\left(200 \mu \mathrm{L} /\right.$ well) and incubated for $90 \mathrm{~min}$ at $37^{\circ} \mathrm{C}$.

iv) Step ii) was repeated.

v) An amount of $100 \mu \mathrm{L}$ of antisera diluted in PBS was added to the wells. The titers used were $1 / 500$ for USDA2667, 1/5 000 for CIAT899 and HB, and $1 / 10000$ for USDA2669, USDA2676 and IRATYH1 12. Plates were incubated for $90 \mathrm{~min}$ at $37^{\circ} \mathrm{C}$ and for $30 \mathrm{~min}$ at $4{ }^{\circ} \mathrm{C}$.

vi) Step ii) was repeated.

vii) Goat anti rabbit IgG conjugated with peroxydase (Biorad) was diluted 1000 -fold in PBS and added $(100 \mu \mathrm{L})$ to the wells. 
viii) Step ii) was repeated.

ix) OPD (o-phenylenediamine, Biorad) was used as a substrate $(0.4 \mathrm{mg} / \mathrm{mL}$ in $0.1 \mathrm{M}$ citric acid phosphate buffer, $\mathrm{pH} 5.5$ ). Immediately before use, $8 \mu \mathrm{L}$ of fresh $35 \%$ hydrogen peroxide were added per $20 \mathrm{~mL}$ of substrate. In this study, $200 \mu \mathrm{L}$ of this solution were added to each well.

$\mathrm{x})$ The enzyme reaction was stopped after $15 \mathrm{~min}$ by adding $50 \mu \mathrm{L}$ of $2 \mathrm{M} \mathrm{H}_{2} \mathrm{SO}_{4}$ to each well.

The optical densities were measured at $492 \mathrm{~nm}$. On each plate the optical density of the substrate was measured in wells where no antigen or serum was used as controls and values below 0.05 were normally found. For the reactivity between strains or isolates and antisera, ELISA absorbance values $(492 \mathrm{~nm})$ were normalised against the appropriate positive control as described by Eaglesham and Sinclair (1988). Results from different experiments could thus be compiled into a single data set.

To ensure accuracy of the positive control data, five replicate determinations were made. For other tests, three replicates were performed.

\section{Intact soil core experiment}

Two sites harbouring common bean specific rhizobia were selected to analyse the inoculation effect of three reference strains (CIAT899, USDA2667 and IRATYH112) on two cultivars. Soil samples were collected from these two sites in heavy-duty PVC plastic pipes $($ diameter $=15 \mathrm{~cm}$, height $=25 \mathrm{~cm})$. The main characteristics of soils are given in table II. Bean seeds were sown on these soil cores, watered and protected from contamination as indicated by Beck et al (1993). When they emerged, seedlings were thinned to three and each plant was inoculated with $1 \mathrm{~mL}$ of rhizobial culture containing $10^{9} \mathrm{bact} / \mathrm{mL}$. Five cores were sown per treatment. Irrigation was carried out using sterile water. For the $\mathrm{N}$-control treatment the equivalent of $120 \mathrm{~kg} \mathrm{~N} / \mathrm{ha}$ (in urea form) was added: half 1 week after seedling emergence and half 5 weeks after planting.

Table II. Some chemicals and physical properties of the soils used.

\begin{tabular}{lcc}
\hline Soils & Boucharrai & Chrifet \\
\hline $\mathrm{pH} \mathrm{H}_{2} \mathrm{O}$ & 8.23 & 8.13 \\
$\mathrm{P}_{2} 0_{5} \mathrm{ppm}^{\mathrm{a}}$ & 18.9 & 19.3 \\
${\text { Total soil N }(\%)^{\mathrm{b}}}_{\text {Clay }(\%)}$ & 0.042 & 0.105 \\
Silt $(\%)$ & 14 & 14 \\
Sand $(\%)$ & 4 & 2 \\
$\mathrm{~K}_{2} \mathrm{O}$ ppm & 82 & 84 \\
Organic matter $(\%)$ & 145 & 88 \\
& 0.81 & 0.99
\end{tabular}

a Olsen and Dean (1965); ${ }^{\mathrm{b}}$ Bremner (1965).
Plants were harvested at the mid-anthesis stage after 8 weeks. Shoots were excised, oven-dried and weighed and the total nitrogen analysed (Bremner, 1965). Nodules were enumerated and samples from various treatments were conserved in tubes with anhydrous $\mathrm{CaCl}_{2}$ and stored at $4{ }^{\circ} \mathrm{C}$ until ELISA analysis was performed.

The nodule occupancy study was performed on samples of eight nodules randomly selected from inoculated plants of each soil core. Thus, 40 nodules were analysed by treatment. Nodule occupancy was determined by indirect ELISA according to the methodology of Beck et al (1993). The absorbance was read at $492 \mathrm{~nm}$ and compared to the blanks and positive controls.

\section{Data analysis}

The individual and combined analyses of variance over the two cultivars were performed on the data of the effectiveness trial and the soil core experiment using SAS Software (1994). Then, least significant differences (LSD) were calculated to determine statistical differences between treatments.

\section{RESULTS}

\section{Evaluation of strain effectiveness}

This study was performed to identify efficient strains and isolates. Thus, analysis of variance on data obtained from effectiveness test trial was carried out for the treatment and cultivar factors and their interaction (table III). This analysis showed that the differences between treatments were statistically significant for all studied characteristics. Between cultivars, there was one difference for nodule number and nodule dry weight. Royalnel

Table III. Analysis of variance for shoot dry weight (SDW), nodule number (NN), nodule dry weight (NDW), shoot nitrogen (SN) and total nitrogen (TN) in Coco and Royalnel cultivars inoculated with rhizobia (shown in table I) in the effectiveness test trial.

\begin{tabular}{|c|c|c|c|c|c|}
\hline $\begin{array}{l}\text { Source of } \\
\text { variation }\end{array}$ & $S D W$ & $N N$ & $N D W$ & $S N$ & $T N$ \\
\hline Treatment & $6.9^{\$ * * *}$ & $3.5^{* *}$ & $2.6 * *$ & $3.2 * * *$ & $6.5^{* * *}$ \\
\hline $\begin{array}{l}\text { Cultivar } \\
\text { Cultivar }\end{array}$ & $0.3 \mathrm{NS}$ & $15.7 * * *$ & $5.6^{*}$ & $3.1 \mathrm{NS}$ & $1.8 \mathrm{NS}$ \\
\hline$\times$ treatment & $1.8^{*}$ & $2.4^{*}$ & $2.0^{*}$ & $2.5^{* *}$ & $4.2 * * *$ \\
\hline
\end{tabular}


cultivar showed the highest averages. This cultivar gave 109 nodules/pl and $75 \mathrm{mg}$ nodule dry weight/pl. Averages for Coco cultivar were, respectively, 75 and 64 for the same parameters. For other characters, the difference between cultivars was probably hidden by treatment $x$ cultivar interaction. In fact this interaction was significant for all the characteristics (table III). Then, the analysis of results was performed separately for the two cultivars (table IV). It appeared that for example strain USDA2669 showed SDW (shoot dry weight), SN (total shoot nitrogen) and TN (total plant nitrogen) on Coco cultivar means higher than those observed on Royalnel cultivar. On the other hand, USDA2676 appeared to be more effective on Royalnel cultivar. According to the results obtained with the strain $\times$ cultivar associations (table IV) and when compared with noninoculated $0 \mathrm{~N}$ - and $\mathrm{N}$-control, the studied strains can be grouped according to their effectiveness as shown by SDW, SN and TN on the two cultivars; group i) highly efficient strains: CIAT899, USDA2667, USDA2669, USDA2676 and IRATYH112; group ii) slightly efficient strains:
GB9.6, USDA2668; and group iii) inefficient isolates: HB, 107 and 108.

Correlation analysis (data not shown) indicated that SDW, SN and TN, followed similar patterns and showed significant positive correlation. These parameters could be considered as accurate criteria for symbiotic activity analysis on common bean and then could be used for screening of further strain $\times$ cultivar treatments for their symbiotic effectiveness in sterile cup system.

\section{Serological relatedness of the common bean rhizobia strains and isolates}

Reaction of pure culture from 44 reference strains and local isolates was analysed with the six antisera. The results revealed a wide serological relatedness between the four reference strains CIAT899, USDA2669, USDA2676 and IRATYH112 (table V). These strains form one group and share therefore several common anti-

Table IV. Mean shoot (SDW) and nodule (NDW) dry weight (mg/pl), nodule number (NN) (nod/pl), shoot (SN) and total (TN) nitrogen $(\mathrm{mg} / \mathrm{pl})$ of 6-week-old plants of two common bean cultivars as affected by rhizobial strain treatments under aseptic $\mathrm{N}$-free hydroponic culture.

\begin{tabular}{|c|c|c|c|c|c|c|}
\hline Cultivar & Treatment & $S D W$ & $N N$ & $N D W$ & $S N$ & $T N$ \\
\hline \multirow[t]{13}{*}{ Royalnel } & ON-control & 529 & & & 6 & 9 \\
\hline & $\mathrm{HB}$ & 581 & 113 & 55 & 6 & 10 \\
\hline & 107 & 545 & 73 & 31 & 6 & 10 \\
\hline & 108 & 509 & 84 & 35 & 6 & 10 \\
\hline & GB9.6 & 740 & 136 & 100 & 21 & 30 \\
\hline & CIAT899 & 755 & 118 & 85 & 23 & 33 \\
\hline & USDA2667 & 873 & 114 & 88 & 31 & 39 \\
\hline & USDA2668 & 565 & 138 & 96 & 11 & 18 \\
\hline & USDA2669 & 702 & 102 & 77 & 22 & 32 \\
\hline & USDA2676 & 1021 & 105 & 94 & 32 & 43 \\
\hline & IRATYH112 & 775 & 109 & 86 & 24 & 33 \\
\hline & N-control & 978 & & & 31 & 43 \\
\hline & LSD $(0.05)$ & 132 & 16 & 11 & 2 & 5 \\
\hline \multirow[t]{13}{*}{ Coco } & ON-control & 604 & & & 8 & 15 \\
\hline & HB & 538 & 43 & 28 & 8 & 13 \\
\hline & 107 & 593 & 48 & 35 & 7 & 14 \\
\hline & 108 & 596 & 35 & 21 & 9 & 15 \\
\hline & GB9.6 & 588 & 87 & 81 & 19 & 28 \\
\hline & CIAT899 & 754 & 97 & 75 & 25 & 37 \\
\hline & USDA2667 & 743 & 78 & 66 & 30 & 40 \\
\hline & USDA2668 & 602 & 81 & 90 & 13 & 21 \\
\hline & USDA2669 & 707 & 109 & 84 & 25 & 35 \\
\hline & USDA2676 & 595 & 83 & 79 & 21 & 31 \\
\hline & IRATYH112 & 699 & 85 & 83 & 23 & 33 \\
\hline & N-control & 859 & & & 29 & 43 \\
\hline & $\operatorname{LSD}(0.05)$ & 110 & 13 & 8 & 2 & 4 \\
\hline
\end{tabular}


Table V. ELISA cross-reaction of six antisera to their related strains and 38 local common bean rhizobia isolates.

\begin{tabular}{|c|c|c|c|c|c|c|}
\hline \multirow[b]{2}{*}{ Bacteria } & \multicolumn{6}{|c|}{ Antisera } \\
\hline & $\begin{array}{c}U S D A \\
2667\end{array}$ & $\begin{array}{l}\text { CIAT } \\
899\end{array}$ & $\begin{array}{c}U S D A \\
2669\end{array}$ & $\begin{array}{c}\text { USDA } \\
2676\end{array}$ & $\begin{array}{c}\text { IRATYH } \\
112\end{array}$ & $H B$ \\
\hline \multicolumn{7}{|c|}{ Reference strains: } \\
\hline USDA2667 & $1.00 *$ & $-\S$ & - & - & - & - \\
\hline CIAT899 & - & 1.00 & 0.98 & 0.93 & 0.89 & - \\
\hline USDA2669 & - & 0.90 & 1.00 & 0.87 & 0.78 & - \\
\hline USDA2676 & - & 1.21 & 1.18 & 1.00 & 0.98 & - \\
\hline IRATYH1 12 & - & 0.97 & 0.97 & 0.97 & 1.00 & - \\
\hline \multicolumn{7}{|l|}{ Local isolates: } \\
\hline $\mathrm{HB}$ & - & - & - & - & - & 1.00 \\
\hline $31 \mathrm{c} 3$ & - & - & - & - & - & 0.97 \\
\hline $30 \mathrm{c} 2$ & - & - & - & - & - & 0.95 \\
\hline $33 \mathrm{a} 3$ & - & - & - & - & - & 0.83 \\
\hline $36 \mathrm{c} 1$ & - & - & - & - & - & 0.55 \\
\hline $18 \mathrm{bl}$ & 0.33 & - & - & - & - & - \\
\hline $16 \mathrm{c} 1$ & 0.72 & - & - & - & - & - \\
\hline $34 \mathrm{c} 2$ & 0.76 & - & - & - & - & - \\
\hline $35 \mathrm{c} 2$ & 0.66 & - & - & - & - & - \\
\hline $35 \mathrm{cl}$ & 0.29 & - & - & - & - & - \\
\hline \multicolumn{7}{|l|}{29 other local } \\
\hline isolates $\dagger$ & - & - & - & - & - & - \\
\hline
\end{tabular}

* Normalized absorbance values (NAV). $\S$ indicates less than 0.1 NAV. $\dagger 15 \mathrm{c} 3,20 \mathrm{c} 1,23 \mathrm{c} 1,25 \mathrm{c} 2,28 \mathrm{~b} 3,28 \mathrm{c} 2,31 \mathrm{a} 2,33 \mathrm{c} 3,34 \mathrm{~b} 2$, 35a1, 35b2, 36b3, 37b1, 37c2, 39b2, 1b3, 2b1, 2b3,3b1, 3b3, 6b1, 6b3, 7a3, 7c1, 8a3, 9b1, 10a3, 12a3, $12 \mathrm{~b} 2$.

genic components even if they come from distant geographic regions. However, wide serological differences have been observed between these strains, the local isolates or reference strain USDA2667. In addition, as shown in table V, strain USDA2667 forms its own group and crossreacts with five local strains $(18 \mathrm{~b} 1,16 \mathrm{c} 1,34 \mathrm{c} 2$, $35 \mathrm{c} 2,35 \mathrm{c} 1)$ from the northern region of Tunisia with normalised absorbance values (NAV) ranging from 0.29 to 0.76 . The local strain (HB) for which an antiserum was produced, cross-reacts with four local isolates (table $\mathrm{V}$ ) originated from the north region $(31 \mathrm{c} 3,30 \mathrm{c} 2,33 \mathrm{a} 3,36 \mathrm{c} 1)$ with NAV ranging from 0.55 to 0.97 .

\section{Nodule occupancy of introduced strains and their effect on nodulation and plant growth}

The usefulness of indirect ELISA for the nodule occupancy study of three efficient reference strains (CIAT899, USDA2667 and IRATYH112) on Royalnel and Coco cultivars in Tunisian soils was shown by the analysis of nodules formed by native rhizobia. The analyses of samples of 30 nodules from the two cultivars grown on the soils of Boucharrai and Chrifet showed that none of the antisera raised against the three strains reacted significantly with nodule extracts from nodules formed by native rhizobia. Thus, it was possible to distinguish easily between nodules containing the inoculated strain and those occupied by native rhizobia.

Thereafter, the performance of these strains as inoculants was analysed in a soil core experiment. The effect of inoculated reference strains on soil core grown common bean was studied on $\mathrm{SN}$ (shoot nitrogen), NN (nodule number) and \%NO (percentage of nodule occupancy). Analysis of variance for data of this experiment was performed for the treatment, cultivar and site factors and their interactions. For all parameters, except for SN with site factor (table VI), the results showed highly significant differences between treatments, cultivars and sites. Highly significant interactions between treatment, cultivar and site factors were also obtained for all parameters except for $\mathrm{SN}$ content with cultivar $\times$ treatment interaction.

Comparative analysis of treatments in every site and for the two cultivars is shown in table VII. 
Table VI. Analysis of variance for shoot nitrogen (SN), nodule number (NN) and percent nodule occupancy (\%NO) in Coco and Royalnel cultivar grown on soil cores of Boucharrai and Chrifet with (N-control) or without $(0 \mathrm{~N}$-control) $\mathrm{N}$-fertilizer or inoculated with reference strains (CIAT899, USDA2667 and IRATYH112).

\begin{tabular}{lccc}
\hline $\begin{array}{l}\text { Source of } \\
\text { variation }\end{array}$ & $S N$ & $N N$ & $\% N O$ \\
\hline Site & & & \\
Cultivar & $0.5^{\$} \mathrm{NS}$ & $104.4^{* * *}$ & $304.0^{* * *}$ \\
Treatment & $14.5^{* * *}$ & $438.2^{* * *}$ & $94.5^{* * *}$ \\
Site $\times$ cultivar & $6.5^{* * *}$ & $196.4^{* * *}$ & $12.9^{* * *}$ \\
Cultivar $\times$ treatment & $10.3^{* *}$ & $64.5^{* *}$ & $52.6^{* * *}$ \\
Site $\times$ treatment & $3.1^{* *}$ & $11.2^{* * *}$ & $25.6^{* * *}$ \\
Site $\times$ cultivar & & & $3.6^{* * *}$ \\
$\quad \times$ treatment & $3.4^{* *}$ & $4.9^{* * *}$ & $43.2^{* * *}$ \\
\hline
\end{tabular}

${ }^{\$} \mathrm{~F}$ values, ${ }^{* * *} P \leq 0.001,{ }^{* *} P \leq 0.01, * P \leq 0.05$, NS: not significant.

For shoot nitrogen content, inoculated treatments of Royalnel cultivar grown on soil cores from Boucharraï site gave significantly higher means than that of $0 \mathrm{~N}$-control (table VII). In the same site, Coco cultivar seemed to be less affected than Royalnel cultivar by nitrogen deficiency. In fact, no significant difference was observed between all treatments for that cultivar (table VII). From the results of Chrifet soil cores, nitrogen appeared not to be a limiting factor in this soil for Royalnel cultivar. Consequently, inoculation did not lead to a noticeable improvement of shoot nitrogen. Moreover, Royalnel cultivar inoculated with USDA2667 and IRATYH112 showed significantly lower averages for shoot nitrogen than that of $0 \mathrm{~N}$-control (table VII). In the same site for Coco cultivar, inoculation did not lead to any improvement of SN despite the application of $\mathrm{N}$ fertilizer.

Nodulation, as estimated by $\mathrm{NN}$, was generally improved by inoculation with reference strains. Except for Coco in Chrifet soil inoculation has led to a significant improvement of at least $48 \%$ for CIAT899 in Chrifet for Royalnel cultivar, and reached $73 \%$ for IRATYH112 in Boucharraï soil for Coco cultivar (table VII). On the contrary, the use of urea as $\mathrm{N}$-fertilizer reduced nodule number to about $30 \%$ in Boucharrai soil and to more than

Table VII. Mid anthesis sampling data from inoculated soil core experiment.

\begin{tabular}{|c|c|c|c|c|c|}
\hline Site & Cultivar & Treatment & $S N$ & $N N$ & $\% N O$ \\
\hline \multirow[t]{12}{*}{ Boucharraï } & Royalnel & $\mathrm{N}$-control & 79 & 47 & - \\
\hline & & CIAT899 & 67 & 116 & 93 \\
\hline & & USDA 2667 & 61 & 120 & 65 \\
\hline & & IRATYH1 12 & 62 & 116 & 83 \\
\hline & & $0 \mathrm{~N}$-control & 34 & 80 & - \\
\hline & & $\operatorname{LSD}(0.05)$ & 11 & 12 & 14 \\
\hline & Coco & N-control & 62 & 42 & - \\
\hline & & CIAT899 & 64 & 100 & 43 \\
\hline & & USDA 2667 & 58 & 98 & 23 \\
\hline & & IRATYH1 12 & 57 & 102 & 38 \\
\hline & & $\mathrm{ON}$-control & 60 & 59 & - \\
\hline & & $\operatorname{LSD}(0.05)$ & NS & 13 & 10 \\
\hline \multirow[t]{12}{*}{ Chrifet } & Royalnel & N-control & 77 & 30 & - \\
\hline & & CIAT899 & 67 & 109 & 13 \\
\hline & & USDA 2667 & 50 & 121 & 18 \\
\hline & & IRATYH 112 & 60 & 110 & 13 \\
\hline & & 0N-control & 71 & 74 & - \\
\hline & & $\operatorname{LSD}(0.05)$ & 9 & 8 & NS \\
\hline & Coco & $\mathrm{N}$-control & 65 & 15 & - \\
\hline & & CIAT899 & 9 & 62 & 3 \\
\hline & & USDA2667 & 56 & 61 & 15 \\
\hline & & IRATYH112 & 49 & 57 & 3 \\
\hline & & $0 \mathrm{~N}$-control & 52 & 56 & - \\
\hline & & $\operatorname{LSD}(0.05)$ & 8 & 9 & NS \\
\hline
\end{tabular}

NS = not significant at 0.05 level. SN: shoot nitrogen $(\mathrm{mg} / \mathrm{pl})$. NN: nodule number (nod $/ \mathrm{pl}) . \% \mathrm{NO}$; percentage nodule occupancy by inoculated strains. 
$50 \%$ in Chrifet soil (table VII), compared to the $0 \mathrm{~N}$-control.

Nodule occupancy by inoculated strains showed that all these strains (table VII) are more frequently present than native rhizobia in nodules of Royalnel cultivar grown in Boucharraï soil. On the contrary, for the two cultivars in the Chrifet site, native rhizobia occupied more nodules than inoculant strains. Nodulation of the two cultivars with inoculant strains seems to be more difficult in Chrifet soil than in the other one.

\section{DISCUSSION AND CONCLUSIONS}

Phaseolus vulgaris is an important N-fertilizerdependent crop in Tunisia and no work was carried out to improve its $\mathrm{N}_{2}$-fixation capacity in the field. In spite of its well-established need for inoculation (Dahmane et al, 1995), the process of performance strain selection is not yet developed. The first step in this process is the selection of efficient strains either under laboratory, or glass house conditions.

In this work, effectiveness of seven reference strains and three local isolates of common bean rhizobia was assessed for two common bean cultivars (Royalnel and Coco) in a glass house trial. Interaction between strain or isolate and cultivar was significant for all characteristics (table III). This result confirms those obtained by Graham (1981) and Amarger (1986), who showed that nitrogen fixation depends on strain $\times$ cultivar interaction and that the process of selection of efficient strains should be developed with adequate cultivars. The choice of the cultivars used should be made according to either shoot dry weight, or nitrogen content of shoot plant. The effectiveness test trial showed that studied local isolates were not efficient (table IV) and confirms observations of Dahmane et al (1995) which indicated that nodules on common bean in field are rare and inefficient. However, Mhamdi (unpublished data) recently identified some local effective isolates on Coco cultivar in an effectiveness test trial.

Antisera production was developed to carry out many ecological studies including competitiveness on rhizobia (Kishinevsky and Bar-Joseph, 1978; Ayanaba et al, 1986; Cleyet-Marel, 1987; Evans et al, 1996). Analysis of the serological relatedness of common bean rhizobia collection, according to six antisera (table V) showed that $77 \%$ of local isolates did not react with any of the used antisera, whereas reference strains CIAT899, USDA2669, USDA2676, IRATYH112 and
USDA2667 were distinguishable from the majority of local isolates. This fact may suggest that local native rhizobia should contain many particular antigenic components.

Strains CIAT899, USDA2667 and IRATYH112 were selected for their effectivity on the two cultivars in the effectiveness test trial and studied in a soil core experiment. This inoculation trial was carried out in sites where native strains did not cross-react with reference strains.

The results (table VII) suggest that the growth of Royalnel cultivar in Boucharrai soil was limited by nitrogen availability and that it is possible to improve its nitrogen content by inoculation with selected strains. This was not the case for Coco cultivar. These results confirm those of Peterson and Loynachan (1981) and Salez and SaintMacary (1987) who showed that inoculation can lead to plant $\mathrm{N}$ improvement. The very clear preferential nodulation of Royalnel with strains CIAT899, USDA2667, and IRATYH112 to native rhizobia is comparable to what was described on different cultivars of Glycine spp (Cregan and Keyser, 1988) and white clover (Mytton, 1975). These reference strains could be good candidates for inoculation of this cultivar in that site for further field experiments. In Chrifet soil, Coco cultivar was also limited by nitrogen availability. Yet, inoculation by reference strains could not improve $\mathrm{SN}$; this may be due to soil conditions including chemical components, higher number of native rhizobia or higher competitiveness of native isolates. As shown by Thies et al (1992), adapted native strains are more competitive than inoculated strains in some environments

Unlike $\mathrm{SN}, \mathrm{NN}$ was generally increased by inoculation in the trial (VII). This result may be explained by the behaviour of native and introduced populations of rhizobia. Foreign strains in the rhizosphere, irrespective of the formed nodules, seem to favourize infectivity of native adapted specific rhizobia. Indeed, the number of nodules formed by native rhizobia is improved for inoculated Royalnel in Chrifet soil with at least $28 \%$.

Data in table VII confirm the results obtained by many authors (Schuller et al, 1986; Heakman, 1987; Salez and Saint-Macary, 1987; Minchin et al, 1989) who showed that soil nitrogen is inhibitory for the symbiotic process. Surveys for nodulation of field grown bean over Tunisian soils showed rare and ineffective nodules probably because of the use of generally more than $100 \mathrm{~kg} / \mathrm{ha} \mathrm{N}$-fertilizer. This chemical component 
should be taken into account for the improvement of symbiotic nitrogen fixation.

Generally for the different analysed parameters, analysis of inoculation effect trial data (tables VI) showed significant interactions between analysed factors. This fact emphasizes the important role of nitrogen nutrition status which includes plantassociated rhizobia, relation with cultivars and physicochemical components of soil. Then, as shown by Cleyet-Marel and Pinochet (1986), inoculation should not be considered as a panacea. It represents the issue of a long process and one aspect of a total management program.

Acknowledgments: This work was supported by grant PNM (P92BTL05) from the secrétariat d'État à la Recherche scientifique et à la Technologie. We thank $\mathrm{N}$ Amarger for helpful discussions and $\mathrm{C}$ Bonnier, P Beunard, P Van Berkum for supplying common bean rhizobia strains. We are grateful to $\mathrm{R}$ Laamouri and $\mathrm{Z}$ Belasfar for technical assistance.

\section{REFERENCES}

Amarger N (1986). Nodulation competitiveness among Rhizobium leguminosarum strains. Votr Pflanzenzüchtung 11, 186-194

Ayanaba A, Weiland KD, Zablotowicz RM (1986) Evaluation of diverse antisera, conjugates, and support media for detecting Bradyrhizobium japonicum by indirect enzyme-linked immunosorbent assay. Appl Environ Microbiol 52, 1132-1138

Beck DP, Materon LA, Afandi F (1993) Practical Rhizobium-Legume Technology Manual. Technical manual No 19, ICARDA, 1-389

Bottomley PJ (1992) Ecology of Bradyrhizobium and Rhizobium. In: Biological Nitrogen Fixation (G Stacey et al, eds), Wiley and Sons, London, 293-348

Bremner JM (1965) Total nitrogen. In: Methods of Soil Analysis (CA Black et al, eds), Part 2, Monogr 9 , ASA, Madison, WI, 1149-1179

Cleyet-Marel JC (1987) Dynamique des populations de Rhizobium et de Bradyrhizobium dans le sol et la rhizosphère. Doctorat d'État, université ClaudeBernard-Lyon-I, $240 \mathrm{p}$

Cleyet-Marel JC, Pinochet X (1986) Selection of symbiotic legume bacteria. State of the art and potential application. Symbiosis 2, 175-185

Cregan PB, Keyser HH (1988) Influence of Glycine spp on competitiveness of Bradyrhizobium japonicum and Rhizobium fredii. Appl Environ Microbiol 54, 803-808

Dahmane A, Ouchari H, Labidi M, Mouldi A, Baatour A, Gabsi S (1995) Acquis des recherches sur la présence et l'efficience des Rhizobium autochtones spécifiques des principales légumineuses alimentaires cultivées en Tunisie. In: Facteurs limitant la fixation symbiotique de l'azote dans le bassin mediterranéen (JJ Drevon, ed), Inra, Paris, 175-182

Dolhem-Biremon C, Mary P, Tailliez R (1992) Compétition entre souches de Rhizobiaceae. Mise en évidence de différents modes d'adhésion sur les racines de soja. Can J Microbiol 39, 982-986

Eaglesham ARJ, Sinclair MJ (1988) Identification and characterization of rhizobia using the ELISA technique. In: Nitrogen Fixation by Legumes in Mediterraneen Agriculture (DP Beck, LA Materon, eds), Martinus Nijhoff Publishers, Dordrecht, 195206

Evans J, Gregory A, Dobrowolski N, Morris SG, O'Connor GE, Wallace C (1996) Nodulation of field-grown Pisum sativum and Vicia faba: competitiveness of inoculant strains of Rhizobium leguminosarum by viciae determined by an indirect, competitive ELISA method. Soil Biol Biochem 28, 247 255

Graham PH (1981) Some problems of nodulation and symbiotic nitrogen fixation in Phaseolus vulgaris (L): a review. Field Crops Res 4, 93-112

Graham PH (1992) Stress tolerance in Rhizobium and Bradyrhizobium and nodulation under adverse soil condition. Can J Microbiol 38, 475-484

Heckman MO (1987) Influence du métabolisme nodulaire du nitrate sur l'inhibition de la fixation symbiotique d'azote chez le soja (Glycine $\max (\mathrm{L})$ ). Thèse de doctorat, université des sciences et techniques du Languedoc, $162 \mathrm{p}$

Keatinge JDH, Chapanian N, Saxena MC (1988) Effect of improved management of legumes in a legume cereal rotation of field estimates of crop nitrogen uptake and symbiotic nitrogen fixation in northern Syria. J Agric Sci Camb 110, 651-659

Kishinevsky B, Bar-Joseph M (1978) Rhizobium strain identification in Arachis hypogea nodules by enzyme-linked immunosobent assay (ELISA). Can J Microbiol 24, 1537-1543

Larue TA, Patterson TG (1981) How much nitrogen do legumes fix? Adv Agron 34, 15-38

Minchin FR, Becana M, Sprent JI (1989) Short-term inhibition of legume $\mathrm{N}_{2}$ fixation by nitrate. Planta $10,46-52$

Mytton LR (1975) Plant genotype $\times$ Rhizobium strain interactions in white clover. Ann Appl Biol 80, 103107

Olsen SR, Dean LA (1965) Phosphorus. In: Methods of Soil Analysis (CA Black et al, eds), Part 2, Monogr 9, ASA, Madison, WI, 1039-1049

Peterson HL, Loynachan TE (1981) The significance and application of Rhizobium in agriculture. Int Rev Cytol Suppl 13, 311-331

Salez P, Saint-Macary H (1987) Inoculation du haricot (Phaseolus vulgaris) par Rhizobium phaseoli au Cameroun. Agronomie Tropicale 42, 269-274

Schuller KA, Day DA, Gibson AH, Gresshoff PM (1986) Enzymes of ammonia assimilation and urei- 
de biosynthesis in Soybean nodules: Effect of nitrate. Plant Physiol 80, 646-650

Smith SC, Bezdicek DF, Turco RF, Cheng HH (1987) Seasonal N $\mathrm{N}_{2}$ Fixation by cool-season pulses based on several $\mathrm{N}^{15^{2}}$ methods. Plant Soil 97, 3-13

Somasegaran P, Hoben HJ (1985) Methods in legumeRhizobium technology. University of Hawaii NifTAL Project, Paia, Hawaii, 367 p

Thies JE, Ben Bohlool B, Singleton PW (1992) Environmental effects on competition for nodule occupancy between introduced and indigenous rhizobia and among introduced strains. Can $J$ Microbiol 38, 493-500

Vincent JM (1970) A Manual for the Practical Study of the Root Nodule Bacteria. IBP Handbook No 15 Oxford, Edinburgh Blackwell Sci Publ, $164 \mathrm{p}$

Wolff AB, Streit W, Kipe-Nolt JA, Vargas H, Werner D (1991) Competitiveness of Rhizobium leguminosarum bv phaseoli strains in relation to environmental stress and plant defense mechanisms. Biol Fertil Soils 12, 170-176 